\author{
JÓZEF FRĄCKOWIAK \\ ORCID: 0000-0003-3076-0986 \\ Uniwersytet Wrocławski (profesor emerytowany) \\ Sąd Najwyższy (SSN w stanie spoczynku)
}

\title{
MIEJSCE PRAWA HANDLOWEGO W SYSTEMIE PRAWA I SPOSOBY JEGO REGULACJI
}

\begin{abstract}
Abstrakt: Opracowanie koncentruje się na dwóch zagadnieniach - miejscu prawa handlowego w systemie prawa oraz sposobach regulacji prawa handlowego. Odnośnie do pierwszego z nich przedstawiono argumenty za traktowaniem prawa handlowego jako działu (dyscypliny) prawa prywatnego. W odniesieniu zaś do regulacji prawa handlowego wskazano powody niereaktywowania kodeksu handlowego. Podkreślono, że kodeks cywilny nienależycie pełni funkcję części ogólnej prawa handlowego. Zaproponowano powołanie akademickiego zespołu prawa handlowego, który po dogłębnym przedyskutowaniu, czy część ogólna prawa handlowego powinna znaleźć się w nowym kodeksie handlowym, odrębnej ustawie czy po udoskonaleniu jej powinna pozostać w kodeksie cywilnym, zaproponowałby projekt odpowiednich przepisów.
\end{abstract}

Słowa kluczowe: prawo handlowe, część ogólna prawa handlowego, kodeks handlowy, przedsiębiorca, czynność handlowa, uchwała, czynności prawne wewnątrzkorporacyjne, kodeks cywilny, prawo prywatne, dział prawa prywatnego

Jeżeli jako kryterium, za pomocą którego wyróżniamy różne obszary regulacji prawnej, przyjąć metodę regulacji, to cały system prawny możemy podzielić na prawo prywatne i prawo publiczne. Tam, gdzie ustawodawca adresatów normy prawnej traktuje na zasadzie równorzędności i pozostawia im szeroko zakrojoną możliwość (autonomię) wpływania na ostateczny kształt tej normy ${ }^{1}$, mamy do

${ }^{1} \mathrm{Z}$ reguły ujmuje się w doktrynie tę normę jako stosunek cywilnoprawny, wskazując, z jakich źródeł pochodzą elementy potrzebne do jego ustalenia. Są to przepis prawny, umowa oraz normy pozaprawne, do których ustawa lub umowa odsyła. Ważną rolę w ustalaniu stosunku prawnego odgrywają orzecznictwo oraz doktryna. Tak rozumiany i ukształtowany stosunek prawny jest w istocie normą prawną, którą stosujemy. Szerzej na ten temat zob. J. Frąckowiak, Stosunek prawny a norma prawa stosowanego, [w:] Ius est a Iustitia Appelatum. Ksiega jubileuszowa dedykowana Profesorowi Tadeuszowi Wiśniewskiemu, Warszawa 2017, s. 789-803. 
czynienia z prawem prywatnym. Jego podstawową częścią jest prawo cywilne zawierające normy mające znaczenie dla całego prawa prywatnego. Oprócz prawa cywilnego do prawa prywatnego należą także wyspecjalizowane działy (dyscypliny) prawa, w których metoda prywatnoprawna ma podstawowe znaczenie, a także gałęzie prawa, w których normy o innym charakterze mają jedynie znacznie pomocnicze, na przykład prawo pracy. W wyspecjalizowanych dyscyplinach prawa prywatnego kodeks cywilny także znajduje zastosowanie, ale mają one również własną, odrębną regulację. Dlatego do prawa prywatnego można zaliczyć prawo rodzinne i opiekuńcze, prawo pracy, a także prawo handlowe, a nawet — chociaż jest to może najbardziej dyskusyjne - cywilne prawo procesowe ${ }^{2}$. Takie ujmowanie prawa prywatnego pozwala na wyraźniejsze określenie wzajemnych relacji między poszczególnymi działami i gałęziami je tworzącymi oraz wskazanie wspólnych cech regulacji prywatnoprawnej i wyodrębnienie instytucji oraz pojęć mających znaczenie w obrębie całego prawa prywatnego ${ }^{3}$. Chociaż w dotychczasowych wypowiedziach o miejscu prawa handlowego przeważa stanowisko, że jest to dyscyplina będąca działem prawa cywilnego ${ }^{4}$, to wydaje się, że lepszym rozwiązaniem jest uznanie, iż prawo handlowe jest odrębnym działem prawa prywatnego. Za takim ujęciem przemawia kilka ważkich argumentów.

Jako odrębna gałąź prawa prywatnego prawo handlowe zostało ujęte w pierwszej kodyfikacji prawa prywatnego po odzyskaniu państwowości przez Polskę, obejmującej oprócz kodeksu zobowiązań także kodeks handlowy. Chociaż taka wyraźna odrębność zanikała wraz z odchodzeniem od gospodarki rynkowej i zniknęła formalnie po uchyleniu tego kodeksu w 1965 roku$^{5}$, to po 1989 roku rozpoczęto przywracanie instytucji prawa handlowego. Pomimo odejścia od dualizmu prawa prywatnego po 1989 roku, czyli po przywróceniu liberalnej go-

2 Zob. bliżej M. Safjan, [w:] System Prawa Prywatnego — część ogólna, red. M. Safjan, Warszawa 2012, s. 32-76 i powołana tam literatura

3 Przy takim podejściu do ujmowania prawa prywatnego dobrym przykładem może być możliwość uporządkowania klasyfikacji adresatów norm prawa prywatnego. Za pomocą kryterium kwalifikacji prawnej możemy wtedy podzielić wszystkich adresatów na następujące grupy: podmioty prawa, pośród których wyróżniamy mające zdolność prawną, czyli osoby (fizyczną, prawną, ustawową, innymi słowy jednostki organizacyjne, o których mowa w art. $33^{1}$ k.c.), podmioty nieosobowe (tacy adresaci mogą być podmiotem tylko niektórych stosunków prawnych, na przykład każda jednostka organizacyjna może być pracodawcą) oraz pozostałych adresatów norm prawa prywatnego. Ta ostatnia grupa jest bardzo zróżnicowana i trudno ją dalej dzielić. Obejmuje ona tych adresatów norm prawa prywatnego, których ustawodawca wyposaża w szczególną zdolność sądową. Są to na przykład zarząd i rada nadzorcza spółek kapitałowych, prokurator, a nawet samo pełnienie funkcji na przykład redaktora naczelnego lub syndyka. Szerzej na temat tej ostatniej grupy adresatów norm prawa prywatnego zob. M. Dziurda, Szczególna zdolność sądowa, Warszawa 2019, s. 167 n.

${ }^{4}$ Zob. przegląd tych stanowisk w S. Włodyka, Prawo handlowe w systemie prawa, [w:] System Prawa Handlowego - część ogólna, red. S. Włodyka, Warszawa 2009, s. 20-48.

5 Zob. art. VI ustawy z dnia 23 kwietnia 1964 roku Przepisy wprowadzające kodeks cywilny (Dz.U. Nr 16, poz. 94), który uchylił kodeks handlowy, pozostawiając w mocy przepisy o spółkach kapitałowych i spółce jawnej 
spodarki rynkowej, pojawiło się wiele regulacji dotyczących prawa prywatnego gospodarczego ${ }^{6}$. W konsekwencji prawo handlowe ma wyraźnie odrębną regulację zawartą w ustawach mających zastosowanie tylko lub prawie wyłącznie do przedsiębiorców, a więc podstawowego adresata norm prawnohandlowych. Warto dodać, że termin „,przedsiębiorca”, wywodzący się od „kupca”, poprzez jednostkę gospodarki uspołecznionej i podmiot gospodarczy jest podstawowym kryterium służącym określeniu, co rozumiemy przez prawo handlowe. Przykładem wspomnianych ustaw tworzących prawo handlowe są: kodeks spółek handlowych ${ }^{7}$, ustawa o Krajowym Rejestrze Sądowym ${ }^{8}$, ustawa o europejskim zgrupowaniu interesów gospodarczych i spółce europejskiej ${ }^{9}$, ustawa o zwalczaniu nieuczciwej konkurencji ${ }^{10}$, prawo upadłościowe ${ }^{11}$. W ustawach tych stosujemy zawartą w nich regulację, a dopiero posiłkowo prawo cywilne ${ }^{12}$. Również kodeks cywilny reguluje istotne elementy prawa handlowego: określenie przedsiębiorcy, prokurę, firmę oraz umowy, w których po jednej stronie występuje przedsiębiorca. W prawie handlowym konieczne jest właściwe określenie pojęć odgrywających rolę przede wszystkim w tym obszarze regulacji, takich jak „przedsiębiorca”, „,czynność handlowa”, „prokura”, „,zynność wewnątrzkorporacyjna” (,uchwała”). Inne są warunki dotyczące staranności wymaganej od przedsiębiorców oraz terminy przedawnienia roszczeń im przysługujących. Można także wskazać zasady prawa handlowego, które da się wywieść z norm tworzących prawo handlowe ${ }^{13}$. Wydaje się więc, że zamiast uznawać prawo handlowe za dział prawa cywilnego, lepiej ich wzajemne odrębności i związki ujmować w ten sposób, że prawo handlowe jest działem prawa prywatnego.

W prawie prywatnym, jak już wskazano, podstawowe znaczenie odgrywa prawo cywilne, które zresztą do niedawna było utożsamiane z prawem prywatnym i z tego względu zapewne pojawił się pogląd, że prawo handlowe jest działem prawa cywilnego. Aktualnie, skoro uznajemy, że w prawie prywatnym występują jeszcze inne działy i gałęzie prawa, wskazane odrębności prawa handlowego uza-

${ }^{6}$ Takie określenie w miejsce prawa handlowego proponowano także w polskiej doktrynie, ale ostatecznie zwyciężyła, jako mająca długotrwałą tradycję, nazwa „prawo handlowe”.

${ }^{7}$ Ustawa z dnia 15 września 2000 roku Kodeks spółek handlowych (tekst jedn. Dz.U. z 2019 r. poz. 505).

${ }^{8}$ Ustawa z dnia 20 sierpnia 1997 roku o Krajowym Rejestrze Sądowym (tekst jedn. Dz.U. z 2019 r. poz. 1500).

9 Ustawa z dnia 4 marca 2005 roku o europejskim zgrupowaniu interesów gospodarczych i spółce europejskiej (tekst jedn. Dz.U. z 2018 r. poz. 2036).

10 Ustawa z dnia 16 kwietnia 1993 roku o zwalczaniu nieuczciwej konkurencji (tekst jedn. Dz.U. z 2019 r. poz. 1010).

11 Ustawa z dnia 28 lutego 2003 roku Prawo upadłościowe (tekst jedn. Dz.U. z 2019 r. poz. 498).

12 Podkreśla to wyraźnie art. 2 kodeksu spółek handlowych.

13 Zob. K. Kopaczyńska-Pieczniak, Zasady prawa handlowego jako element jego części ogólnej, [w:] Kodeks spótek handlowych po 15 latach obowiązywania, red. J. Frąckowiak, Warszawa 2018, s. 54 n. 
sadniają uznanie prawa handlowego za odrębny dział (dyscyplinę) prawa prywatnego. Zazwyczaj wyraźną oznaką, że mamy do czynienia z gałęzią prawa, jest posiadanie przez nią własnego kodeksu podkreślającego jej odrębność. Warto wobec tego wyjaśnić, dlaczego aktualnie polskie prawo handlowe, chociaż ma wyraźne, sobie tylko właściwe cechy, nie ma odrębnego kodeksu handlowego. Czy jest to racjonalny, celowy zabieg, czy też inne czynniki mają na to wpływ. Wymaga to krótkiej analizy rozwoju prawa handlowego po odzyskaniu przez Polskę własnej państwowości — na początku ubiegłego wieku — aż do czasów współczesnych.

Historia regulacji stosunków gospodarczych metodą prywatnoprawną (prawa handlowego) w Polsce wskazuje, że mamy do czynienia nie z harmonijny w miarę rozwojem tej regulacji, ale ze zmianami, które spowodowane przede wszystkim obiektywnymi przyczynami doprowadziły do aktualnego stanu ${ }^{14}$. Niewątpliwym atutem ustawodawcy, który tworzył podwaliny polskiego prawa handlowego w pierwszej połowie XX wieku, było zaplecze w postaci bardzo kompetentnego grona wybitnych prawników, świetnie znających prawo austriackie, niemieckie, francuskie i rosyjskie, albowiem $\mathrm{w}$ tych systemach prawnych, ze względu na pozostawanie ziem polskich pod zaborami, zdobywali oni swoje prawnicze wykształcenie. Pozwoliło to na stosunkowo szybkie przygotowanie nowego polskiego prawa, które uwzględniało dorobek europejskiego prawa prywatnego pierwszej połowy XX wieku. Po ustawach dotyczących fragmentów prawa handlowego (rejestru handlowego, spółki z o.o. oraz spółki akcyjnej) uchwalono kodeks handlowy składający się z dwóch ksiąg. Pierwsza dotyczyła kupców, czyli osób, które zostały wyróżnione poprzez techniczno-prawny termin ,prowadzenie przedsiębiorstwa". Druga księga była poświęcona czynnościom handlowym. Zamierzeniem twórców kodeksu handlowego było stworzenie kolejnej księgi, dotyczącej prawa morskiego i ubezpieczeniowego. Polski ustawodawca obrał więc sposób regulacji stosunków handlowych, który przeważał w krajach przyjmujących zarówno germański, jak i romański porządek prawny. Poza kodeksem handlowym miały pozostać takie działy prawa handlowego jak prawo upadłościowe i prawo układowe. Oprócz kodeksu poświęconego powszechnym stosunkom prywatnoprawnym, kodeksu zobowiązań, uchwalono odrębną całościową regulację dotyczącą stosunków handlowych, czyli wspomniany kodeks handlowy. Przestał on jednak obowiązywać na ziemiach polskich po „czwartym rozbiorze” w 1939 roku. Po odzyskaniu zaś niepodległości, w związku ze zmianami ustrojowymi

14 Szerzej na ten temat zob. J. Frąckowiak, Osiemdziesiat lat polskiego prawa handlowego wzloty, upadki oraz mozolna reaktywacja, „Przegląd Prawa i Administracji” 101. Osiemdziesią lat polskiego prawa handlowego, red. J. Frąckowiak, Wrocław 2015, s. 45 n. 
i zastępowaniu liberalnej gospodarki rynkowej socjalistyczną gospodarką opartą na priorytecie własności państwowej i gospodarce planowej centralnie sterowanej, został stopniowo pozbawiony znaczenia, aby formalnie zostać uchylony wraz z wejściem w życie kodeksu cywilnego. Prawo handlowe ze względu na zupełnie inny układ stosunków gospodarczych zniknęło z polskiej rzeczywistości prawnej na długie dziesięciolecia. Dopiero w latach dziewięćdziesiątych XX wieku rozpoczął się proces przywracania prawa handlowego do polskiego porządku prawnego. Przez ostatnie trzydzieści lat wiele zostało zrobione w tej materii, ale widoczny jest podstawowy problem — brakuje dobrej części ogólnej prawa handlowego.

Rodzi się zasadnicze pytanie, dlaczego polski ustawodawca, mając po przywróceniu gospodarki rynkowej gotowy akt normatywny, jakim był kodeks handlowy, nie zdecydował się na jego przywrócenie, ewentualnie z konieczną jego modernizacją. Znaczenie zdają się tu mieć trzy czynniki. Inaczej niż w początkach XX wieku, po 1989 roku, kiedy nadszedł czas regulacji dotyczących gospodarki rynkowej opartej na zasadzie wolności gospodarczej, brakowało w istocie znawców problematyki prawnohandlowej. Pokolenie przedwojennych komercjalistów zniknęło w naturalny sposób, a stosunki gospodarcze przez kilkadziesiąt lat były regulowane bez potrzeby sięgania po dorobek prawa handlowego, gdyż w nowej rzeczywistości pojawiło się, zupełnie inaczej konstruowane, prawo obrotu uspołecznionego lub prawo gospodarcze ${ }^{15}$. Jednocześnie, przywracając swobodę podejmowania i prowadzenia działalności gospodarczej, ustawodawca uznał, że konstrukcje kodeksu handlowego, szczególnie obowiązek sądowej rejestracji podmiotów prowadzących tę działalność, przy ówczesnej wydolności sądów byłyby hamulcem rozwoju przedsiębiorczości. Najważniejsze zaś dla rozwoju gospodarki opartej na zasadzie swobody gospodarczej wydawało się pobudzenie jak najwięcej podmiotów do podejmowania działalności gospodarczej. Zdecydowano się więc na oryginalne rozwiązania w ustawie, której celem było przede wszystkim ograniczenie administracyjnego wpływu na gospodarkę. Doprowadziło to do sytuacji, w której stosunki tradycyjnie regulowane przez prawo handlowe zostały ujęte w ustawie mającej przede wszystkim charakter administracyjnoprawny ${ }^{16}$. Ten sposób regulacji z niewielkim korektami przetrwał do dzisiaj.

Znamienne jest, że do 2003 roku definicja przedsiębiorcy znajdowała się tylko w ustawach będących źródłem administracyjnego prawa gospodarczego ${ }^{17}$.

15 Na temat prawa gospodarczego zob. M. Madey, A. Stelmachowski, Zarys prawa gospodarczego, Warszawa 1980, s. 13 n.; S. Włodyka, Koncepcja polskiego prawa gospodarczego w warunkach nowego systemu zarządzania gospodarka, Kraków 1973.

16 Ustawa z dnia 23 grudnia 1988 roku o działalności gospodarczej (Dz.U. Nr 41, poz. 324 ze zm.) wprowadzała zasadę swobody działalności gospodarczej i ograniczała ingerencję administracji w działalność gospodarczą, a także określała instrumenty ograniczające działalność gospodarczą.

17 Najpierw w ustawie o działalności gospodarczej wprowadzono nowe określenie na osoby prowadzące działalność gospodarczą — „podmiot gospodarczy”, które zostało zastąpione przez określenie ,przedsiębiorca” w art. 12-99 ustawy z dnia 20 sierpnia 1997 roku - Przepisy wprowadzające ustawę o Krajowym Rejestrze Sądowym (Dz.U. Nr 121, poz. 770 ze zm.). Także kolejna 
Chociaż obecnie w kodeksie cywilnym mamy definicję przedsiębiorcy, to jej element konstrukcyjny, czyli prowadzenie działalności gospodarczej, jest opisany w ustawie o charakterze przede wszystkim administracyjnoprawnym ${ }^{18}$, co skłania wielu autorów zajmujących się prawem handlowym do sięgania po tę definicję przy określaniu rozumienia pojęcia przedsiębiorcy w art. $43^{1}$ k.c. Podstawowe określenie dla prawa handlowego, czyli „przedsiębiorca”, jest od 2003 roku, z trudnych do wyjaśnienia racjonalnie powodów, definiowane dwutorowo - w kodeksie cywilnym oraz $\mathrm{w}$ ustawach regulujących przede wszystkim problematykę prawnoadministracyjną ${ }^{19}$. Wydaje się, że to niewyraźne oddzielenie regulacji prywatnoprawnej od publicznoprawnej i tworzenie ustaw kompleksowo ujmujących regulację stosunków gospodarczych także przyczynił się do tego, że nie ma odrębnego kodeksu handlowego. Taki system regulacji wiązał się z tym, że od wejścia w życie kodeksu cywilnego zaniknął w sensie formalnym i realnym dualizm regulacji stosunków gospodarczych. Kodeks ten ugruntował tak zwane monistyczne podejście do regulacji stosunków gospodarczych. Stosunki między podmiotami gospodarczymi, którymi były wtedy jednostki gospodarki uspołecznionej, zostały wyraźnie objęte regulacją kodeksu cywilnego. Dlatego gdy przywrócono gospodarkę rynkową, brakowało wyraźnych bodźców do odejścia od monistycznej regulacji stosunków gospodarczych. Wraz z utrwaloną tendencją do regulowania stosunków gospodarczych także metodą administracyjnoprawną oraz wspomnianymi czynnikami spowodowało, że nie uznano za celowe przywrócenie odrębnego kodeksu handlowego. Tendencja ta utrzymała się i regulacja polskiego prawa handlowego przyjęła postać regulacji poszczególnych działów tworzących prawo handlowe. W wiodącej ustawie — kodeksie spółek handlowych — twórcy wyraźnie to podkreślili, wskazując, że w sprawach nieuregulowanych stosuje się kodeks cywilny i w konsekwencji jest to przejaw zasady monizmu, również w prawie handlowym najważniejszą rolę odgrywa ostatecznie kodeks cywilny.

Takie podejście, gdy przez wiele lat w kodeksie cywilnym nie było nawet definicji przedsiębiorcy, spowodowało niejako z konieczności pojawienie się tej definicji w ustawach o charakterze przede wszystkim administracyjnoprawnym. Głównym skutkiem usunięcia kodeksu handlowego było więc niezawarcie podstawowych pojęć funkcjonujących w tym kodeksie, czyli części ogólnej prawa handlowego, w ustawie stanowiącej źródło prawa prywatnego. Ta pustka jest wypełniana od 1988 roku do dziś - część tych pojęć pojawia się w ustawach mających przede wszystkim znaczenie dla publicznego prawa gospodarczego. Warto

ustawa, która zastąpiła ustawę o działalności gospodarczej, czyli ustawa z dnia 19 listopada 1999 roku Prawo działalności gospodarczej (Dz.U. Nr 101, poz. 1178 ze zm.), posługiwała się już określeniem ,przedsiębiorca”, podobnie jak jej następczyni, czyli ustawa z dnia 2 lipca 2004 roku ustawa o swobodzie działalności gospodarczej (tekst jedn. Dz.U. z 2007 r. Nr 155, poz. 1095).

18 Zob. art. 3 ustawy z dnia 6 marca 2018 r. Prawo przedsiębiorców (Dz.U. z 2019 r. poz. 1292).

19 Zob. art. 2 ustawy Prawo działalności gospodarczej oraz art. 3 ustawy Prawo przedsiębiorców. 
więc podjąć dyskusję, w jaki sposób doprowadzić do tego, aby współczesne polskie prawo handlowe tworzyło spójny system, co niewątpliwie wymaga nie tylko dobrych rozwiązań poszczególnych działów tego prawa, lecz także zbudowania, w znacznej części od podstaw, części ogólnej prawa handlowego. Nasuwają się tu dwa rozwiązania - albo stworzyć nowy polski kodeks handlowy, albo w ramach odrębnej ustawy bądź kodeksu cywilnego wprowadzić niezbędne do sprawnego funkcjonowania polskiej gospodarki pojęcia podstawowe prawa handlowego, przede wszystkim właściwe normatywne definicje przedsiębiorcy oraz czynności handlowej, a także wrócić do wyraźnej odrębności w regulacji stosunków prywatnoprawnych i publicznoprawnych dotyczących działalności gospodarczej. Ta dwutorowość w regulacji stosunków gospodarczych jest zapewne w jakieś mierze pozostałością po stworzonym w okresie gospodarki centralnie sterowanej specjalnym dziale prawa, tak zwanym prawie gospodarczym lub prawie obrotu uspołecznionego, w którym współistniały regulacje prywatnoprawne i publicznoprawne, co miało swoje uzasadnienie w dobie wyraźnego odrzucenia podziału na prawo prywatne i publiczne.

Niezależnie od tego, którą ze wskazanych metod się obierze, należy rozpocząć od zerwania z istnieniem dwóch normatywnych definicji przedsiębiorcy. Jak wiadomo, przy definiowaniu przedsiębiorcy decydujące znaczenie mają dwa elementy. Trzeba wskazać spośród wszystkich adresatów norm prawa prywatnego, kto może być przedsiębiorcą, oraz określić działalność, której prowadzenie pozwala na zaliczenie tego adresata do grupy przedsiębiorców. W kodeksie handlowym ustawodawca do wyznaczenia pojęcia przedsiębiorcy (kupca) posłużył się określeniem „kto”. Po przywróceniu gospodarki rynkowej podjęto próby bliższego wyznaczenia kręgu podmiotów, które można uznawać za przedsiębiorców ${ }^{20}$. Ostatecznie w k.c. ustawodawca wprowadził oprócz osób fizycznych i prawnych trzeci rodzaj osób - osoby ustawowe. Definiując przedsiębiorcę, uznano, że oprócz osoby fizycznej i prawnej może nim być także jednostka organizacyjna niebędąca osobą prawną, której ustawa przyznaje zdolność prawną. Podmiotowe ujęcie przedsiębiorcy można uznać za poprawne ${ }^{21}$, chociaż wy-

20 Były to takie określenia jak ,podmiot gospodarczy” w ustawie praw działalności gospodarczej oraz „spółka prawa handlowego” w ustawie Prawo działalności gospodarczej, które słusznie uznawano za określenia zbyt szerokie lub zbyt wąskie. Zob. J. Okolski, D. Wajda, [w:] Prawo handlowe, red. J. Okolski, Warszawa 2008, s. 47-51.

${ }^{21}$ Niestety ustawodawca nie doprowadził do ustalenia jasnych kryteriów, za pomocą których można by ustalić, jakie jednostki organizacyjne należy zaliczyć do jednostek, o których mowa w art. $33^{1}$ k.c. (osób ustawowych). Co więcej, mimo że we wspomnianym przepisie jest recepta na prostą formułę, gdyż wystarczyłoby wskazać, że dana jednostka ma zdolność prawną, to w ustawach 
klucza ono uznanie za przedsiębiorcę spółkę cywilną prowadzącą działalność gospodarczą 22 .

Natomiast $\mathrm{w}$ odniesieniu do drugiego elementu k.c. poprzestał na stwierdzeniu, które przynosi więcej niejasności niż pożytku. Jak wynika z art. $43^{1}$ k.c., przedsiębiorcą jest osoba prowadząca działalność gospodarczą lub zawodową. $\mathrm{W}$ istocie nie ma więc jurydycznej definicji tego ważnego elementu, za pomocą którego wyznaczamy pojęcie przedsiębiorcy. To sprawia, że definicja przedsiębiorcy jest zawarta dalej w ustawie o charakterze przede wszystkim administracyjnoprawnym, gdyż tam odnajdujemy definicję normatywną działalności gospodarczej $^{23}$. Trudno taki stan uznać za pożądany z punktu widzenia prawa handlowego traktowanego jako dział prawa prywatnego. Należałoby wobec tego jak najszybciej dokonać ustalenia poprawnej definicji działalności gospodarczej na potrzeby prawa handlowego. Konieczność ustalenia poprawnej definicji działalności gospodarczej wiąże się również z tym, że prawdopodobnie w celu podkreślenia, że obejmuje ona także wykonywanie wolnych zawodów, przy precyzowaniu, jaka działalność uzasadnia uznanie osoby za przedsiębiorcę, użyto sformułowania „prowadzi działalność gospodarczą lub zawodową”. Rodzi to trudności interpretacyjne, gdyż zasadniczo w innych ustawach, w tym w kodeksie cywilnym, używa się tylko określenia „działalność gospodarcza”. Pojawia się zatem zasadnicze pytanie, czy do działalności zawodowej, pomijając już podstawowy problem, jak tę działalność rozumieć, można stosować, i na jakiej podstawie, przepisy dotyczące działalności gospodarczej24.

Warto także rozważyć, czy nie wrócić do znanego kodeksowi handlowemu pojęcia przedsiębiorcy rejestrowego jako przedsiębiorcy prowadzącego działalność gospodarczą w większym rozmiarze. Wiąże się to ze zmianami w regulacjach dotyczących rejestracji i ewidencji działalności gospodarczej. Aktualny stan, który jest kontynuacją wprowadzonej tylko na pewien czas ewidencji działalności gospodarczej, utrzymuje się ze szkodą dla przejrzystości ustalania w rejestrze wpisów

uchwalanych przeszło dziesięć lat później używa się bez żadnego uzasadnienia rozbudowanej formuły z kodeksu spółek handlowych „może we własnym imieniu nabywać prawa, w tym własność nieruchomości i inne prawa rzeczowe, zaciągać zobowiązania, pozywać i być pozywana”, która miała wtedy pewne uzasadnienie, ale po wprowadzeniu wyraźnej podstawy normatywnej w art. $33^{1}$ k.c. i nowelizacji k.p.c. od 7 października 2007 roku nie ma żadnych podstaw do posługiwania się nią. Zob. art. 40 ust. 1a ustawy z dnia 7 kwietnia 1989 r. Prawo o stowarzyszeniach, dodany przez art. 1 pkt 17 lit. a ustawy z dnia 25 września 2015 roku (Dz.U. z 2015 r. poz. 1923) zmieniającej niniejszą ustawę z dniem 20 maja 2016 roku; oraz art. 179 ust. 1 ustawy z dnia 11 września 2015 roku o działalności ubezpieczeniowej i reasekuracyjnej (tekst jedn. Dz.U. z 2019 r. poz. 381).

${ }^{22}$ Spółka cywilna prowadząca działalność gospodarczą powinna mieć zdolność prawną i być traktowana jako odrębny od wspólników przedsiębiorca, gdyż w ten sposób unikamy sztucznej w istocie konstrukcji przyjmowanej także w ustawie Prawo przedsiębiorców, że przedsiębiorcami są tylko wspólnicy spółki cywilnej.

23 Zob. art. 3 ustawy Prawo przedsiębiorców.

${ }^{24}$ Na przykład czy do działalności zawodowej należy stosować art. 118 k.c. i art. 355 § 2 k.c., które odnoszą się wprost tylko do działalności gospodarczej. 
przedsiębiorców. Można rozważyć wpisywanie do rejestru przedsiębiorców także tych będących osobami fizycznymi, jeżeli prowadzą one działalność w większym rozmiarze. Natomiast wszystkich pozostałych przedsiębiorców, czyli prowadzących działalność w mniejszym rozmiarze, należałoby ewidencjonować w uproszczonej formie. Pozwoliłoby to na stosowanie instytucji związanych z rejestrem przedsiębiorców, takich jak prokura czy firma, tylko do przedsiębiorców rejestrowych. Trzeba również rozważyć, jak traktować wykonywanie wolnych zawodów i czy oprócz ewidencji prowadzonej dla każdego z nich należy zobowiązać osoby wykonujące taki zawód do wpisywania się do ewidencji lub do rejestru przedsiębiorców. Aktualnie problem wykonywania wolnych zawodów nie jest jednolicie uregulowany dla całego prawa handlowego, gdyż użyte $\mathrm{w}$ art. $43^{1}$ k.c. określenie, że przedsiębiorcą jest osoba prowadząca działalność gospodarczą lub zawodową nie tylko w niczym nie porząadkuje zagadnienia wykonywania wolnych zawodów, ale wprowadza, jak była o tym mowa, dodatkowe problemy interpretacyjne.

Konieczne wydaje się również stworzenie ustawowych podstaw czynności handlowych. Trudno uznać za właściwą regulację prawa handlowego, jeżeli w ogóle brakuje definicji takiej czynności. Wprawdzie w doktrynie spotykamy próby zaradzenia tej sytuacji ${ }^{25}$, ale niewątpliwie w części ogólnej prawa handlowego powinno znaleźć się takie określenie. Nie wydaje się to trudny zabieg, jeżeli ustalona zostanie poprawna definicja przedsiębiorcy, mając na względzie, że można wykorzystać dobrą definicję czynności handlowej zawartą w kodeksie handlowym. Projektowana część ogólna prawa handlowego powinna także być miejscem, w którym ustali się relacje pomiędzy czynnościami handlowymi a czynnościami wewnątrzkorporacyjnymi (uchwałami organów korporacyjnych przedsiębiorców, przede wszystkim spółek). Zawarta w kodeksie spółek handlowych regulacja uchwał wywołała wiele dyskusji w orzecznictwie i doktrynie, których rozwiązanie bez przemyślanej interwencji ustawodawcy wydaje się niemożliwe. Warto także ustalić relacje pomiędzy pojęciami używanymi w klasycznym prawie cywilnym a posługiwaniem się nimi w prawie handlowym. Nie jest bowiem jasne, czy pełnomocnictwo, o którym mowa w kodeksie spółek handlowych, należy rozumieć swoiście, czy stosować do niego wymogi określone dla pełnomocnictwa w prawie cywilnym.

\section{IV}

Jak wynika z dotychczasowych rozważań, brakuje aktualnie w prawie handlowym części ogólnej, w której stworzono by podstawy normatywne dla pojęć odgrywających ważną rolę w całym prawie handlowym. Powinna to być regulacja ściśle prywatnoprawna. Doświadczenia ostatnich trzydziestu lat pokazują, że ak-

25 Zob. M. Safjan, K. Zaradkiewicz, Pojęcie i rodzaje czynności handlowych, [w:] Prawo handlowe..., s. 599-730. 
tualnie kodeks cywilny nie pełni należycie tej funkcji. Pozostaje do rozważenia, czy taką część ogólną stworzyć w postaci odrębnej ustawy, czy uchwalić nowy kodeks handlowy, czy też doskonalić jednak, mimo złych doświadczeń, regulacje dotyczące prawa handlowego w ramach kodeksu cywilnego. Dotychczasowe doświadczenia pokazują, że to ostatnie rozwiązanie nie daje dobrych rezultatów. Niemniej jednak także pozostałe możliwości udoskonalenia prawa handlowego jako odrębnego działu lub gałęzi prawa prywatnego nie wydają się prostym rozwiązaniem. Niewątpliwie dwadzieścia lat od uchwalenia kodeksu spółek handlowych jest dobrą okazją do rozpoczęcia rzetelnej dyskusji nad tym, czy nie wrócić do koncepcji dwóch kodeksów - cywilnego i handlowego. Wymaga to jednak przede wszystkim rozważenia zakresu takiego kodeksu. Kodeks handlowy objął ostatecznie tylko dwie księgi - jedną poświęconą, jak byśmy określili to współcześnie, przedsiębiorcom, drugą zaś czynnościom handlowym. We współczesnych opracowaniach dotyczących prawa handlowego zalicza się do tej gałęzi prawa prywatnego jednak jeszcze wiele innych działów. Pomimo pewnych różnic do prawa handlowego zalicza się zazwyczaj oprócz prawa przedsiębiorców i czynności handlowych także prawo konkurencji, prawo firmowe, prawo papierów wartościowych czy prawo na dobrach niematerialnych. Ponadto konieczne byłoby przesądzenie, w jakim zakresie do kodeksu handlowego należałoby włączyć regulacje dotyczące poszczególnych przedsiębiorców. Czy idąc śladem kodeksu handlowego, w nowym kodeksie handlowym powinny się znaleźć regulacje dotyczące tylko przedsiębiorców jednoosobowych oraz przedsiębiorców działających w formie spółek, czy także przedsiębiorców działających w innych formach, na przykład przedsiębiorców państwowych czy spółdzielczych. Innym możliwym rozwiązaniem byłoby, tak jak to czyni ustawodawca niemiecki, włączenie do kodeksu handlowego tylko spółek osobowych, a regulację spółek kapitałowych pozostawić w odrębnej ustawie lub ustawach.

Zapewne nie mniejszym problemem byłoby ustalenie, w jakim zakresie włączyć do kodeksu handlowego regulację poszczególnych stosunków powstających z czynności handlowych, mając na uwadze, że wokół wielu tych stosunków prawnych powstały kompleksowe ustawy regulujące całościowo problematykę ubezpieczeń gospodarczych, robót budowlanych czy poszczególnych rodzajów transportu. Nie oznacza to jednak zaniechania dyskusji, czy optymalnym rozwiązaniem dla współczesnego polskiego prawa handlowego nie byłoby jednak stworzenie odrębnego od kodeksu cywilnego kodeksu handlowego. Tak naprawdę zasadę monizmu w regulacji stosunków gospodarczych przeniesiono po przywróceniu gospodarki rynkowej do polskiego prawa handlowego bez pogłębionej dyskusji na ten temat.

Dotychczasowe rozważania prowadzą do wniosku, że najprostszym rozwiązaniem wydaje się stworzenie przepisów, które wypełniłyby widoczną lukę w polskim prawie handlowym w drodze odrębnej ustawy. Pozwoliłoby to na zerwanie z oddziedziczoną po okresie gospodarki sterowanej centralnie niedobrą tendencją do regulowania prawa handlowego w ustawach o charakterze administracyjno- 
prawnym, a także byłoby okazją do stworzenia nowoczesnego zaplecza dla całego polskiego prawa handlowego. Taka ustawa nie zamykałaby drogi ewentualnemu przygotowaniu nowego kodeksu handlowego, jednocześnie byłaby odpowiedzią na złe doświadczenia ostatnich trzydziestu lat, gdy część ogólna prawa handlowego pozostawała w kodeksie cywilnym.

\section{V}

Dobrą okazją do podjęcia prac nad stworzeniem podstaw polskiego prawa handlowego może być okrągła, dwudziesta rocznica wejścia w życie kodeksu spółek handlowych. Mając na uwadze, że aktualnie brakuje instytucjonalnych podstaw do stworzenia komisji prawa handlowego, może warto byłoby spróbować, wzorem cywilistów, zorganizować akademicką komisję prawa handlowego w środowisku polskich komercjalistów, w którym przeważają osoby specjalizujące się w tym prawie przez całą swoją naukową karierę. W ramach tej komisji można by zaplanować i inspirować dyskusję nad docelowym sposobem regulacji polskiego prawa handlowego, ale przede wszystkim wypełnić lukę w postaci części ogólnej prawa handlowego. Po dobrym i wszechstronnym przygotowaniu tej problematyki należałoby podjąć trud przygotowania projektu takiej części w postaci gotowych przepisów. Tylko bowiem projekt takich przepisów, szeroko przedyskutowany przez całe środowisko akademickie polskich komercjalistów, także z udziałem praktyków (sędziów, adwokatów, radców prawnych, notariuszy), daje szansę na to, aby ukazała się w końcu ustawa, w której zostaną jasno i precyzyjnie określone podstawowe, dla dobrego funkcjonowania gospodarki, instytucje polskiego prawa handlowego.

\section{THE PLACE OF COMMERCIAL LAW IN THE SYSTEM OF LAW AND WAYS OF REGULATING}

\section{Summary}

The study focuses on two issues; the place of commercial law in the legal system and methods of regulating it.. As regards the first issue, arguments were presented to treat commercial law as a branch (discipline) of private law. As regards the regulation of commercial law, it was indicated for what reasons the Commercial Code was not reactivated. It was pointed out that the Commercial Code did not properly fulfil the role of the general part of commercial law. It was proposed to set up an academic team for commercial law, which, after thorough discussion of whether the general tenets of commercial law should be included in the new commercial code or a separate act, or whether it should remain in the civil code after its improvement would propose a draft of the relevant provisions.

Keywords: commercial law, general tenets general part - tenets of commercial law, commercial code, entrepreneur, commercial activity, resolution, intra-corporate acts in law, civil code, private law, a branch (discipline) of private law 


\section{BIBLIOGRAFIA}

Dziurda M., Szczególna zdolność sądowa, Warszawa 2019.

Frąckowiak J., Osiemdziesiąt lat polskiego prawa handlowego - wzloty, upadki oraz mozolna reaktywacja, „Przegląd Prawa i Administracji” 101. Osiemdziesiąt lat polskiego prawa handlowego, red. J. Frąckowiak, Wrocław 2015.

Frąckowiak J., Stosunek prawny a norma prawa stosowanego, [w:] Ius est a Iustitia Appelatum. Księga jubileuszowa dedykowana Profesorowi Tadeuszowi Wiśniewskiemu, Warszawa 2017.

Janczewski S., Prawo handlowe. Wekslowe i czekowe, Warszawa 1946.

Kidyba A., Prawo handlowe, Warszawa 2017.

Kopaczyńska-Pieczniak K., Zasady prawa handlowego jako element jego części ogólnej, [w:] Kodeks spótek handlowych po 15 latach obowiazywania, red. J. Frąckowiak, Warszawa 2018.

Madey M., Stelmachowski A., Zarys prawa gospodarczego, Warszawa 1980.

Okolski J., Wajda D., [w:] Prawo handlowe, red. J. Okolski, Warszawa 2008.

Podstawy prawa cywilnego i handlowego dla ekonomistów, red. W.J. Katner, Gdańsk 2001.

Safjan M., [w:] System Prawa Prywatnego — część ogólna, red. M. Safjan, Warszawa 2012.

Safjan M., Zaradkiewicz K., Pojęcie i rodzaj czynności handlowych, [w:] Prawo handlowe, red. J. Okolski, Warszawa 2008.

Włodyka S., Koncepcja polskiego prawa gospodarczego w warunkach nowego systemu zarządzania gospodarka, Kraków 1973.

Włodyka S., Prawo handlowe w systemie prawa, [w:] System Prawa Handlowego - czesść ogólna, red. S. Włodyka, Warszawa 2009. 